\title{
ChemComm
}

\section{Structural insights into the interaction of platinum-based inhibitors with the Alzheimer's disease amyloid- $\beta$ peptide $\dagger$}

\begin{abstract}
Cite this: Chem. Commun., 2013, 49, 11364

Received 25th September 2013, Accepted 22nd October 2013

DOI: $10.1039 / c 3 c c 47326 k$

www.rsc.org/chemcomm

Extended X-ray absorption fine structure spectroscopy, mass spectrometry, dynamic light scattering and density functional theory are combined to derive structural models for the interaction of neurotoxicity-ablating platinum-based compounds with the amyloid- $\beta$ peptide.
\end{abstract}

\author{
Victor A. Streltsov, ${ }^{\text {a }}$ V. Chandana Epa, ${ }^{a}$ Simon A. James, ${ }^{a}$ Quentin I. Churches, ${ }^{a}$ \\ Joanne M. Caine, ${ }^{a}$ Vijaya B. Kenche ${ }^{b}$ and Kevin J. Barnham ${ }^{b}$
}

Alzheimer's disease (AD) is a progressive neurodegenerative disorder and the most common form of dementia in humans. It is characterized pathologically by the presence of large extracellular amyloid plaques in the brain. The main component of these plaques is the 39-43 residue amyloid $\beta$ peptide (A $\beta$ ) which is produced by the sequential cleavage of the amyloid precursor protein (APP) by $\beta$ - and $\gamma$-secretases. However, soluble low molecular weight oligomers of $A \beta$ are shown to exert the neurotoxic effects potently impair synapse structure and function. ${ }^{1,2}$ Anti-AD therapeutic strategies have focused, on the inhibition of the production of $A \beta$, on the inhibition of aggregation of $A \beta$, or on antibody based clearance of $A \beta$.

The aggregation of $A \beta$ is enhanced in the presence of Fe, $\mathrm{Cu}$ and $\mathrm{Zn}^{3-5}$ due to its relatively high affinity towards transition metal ions and cross-linking of peptides. $A \beta-\mathrm{Cu}$ and $\mathrm{A} \beta-\mathrm{Fe}$ complexes are also involved in the production of reactive oxygen species (ROS) under reducing conditions. ${ }^{6,7}$ Unsurprisingly, altering the metal binding activity of $\mathrm{A} \beta$ can inhibit its neurotoxicity. Studies ${ }^{8-13}$ suggest that $\mathrm{Cu}^{2+}, \mathrm{Zn}^{2+}$ and $\mathrm{Fe}^{2+}$ coordinate with the three histidines in the $A \beta$ (His6, His13 and His14). Methylation of the imidazole side chains on these histidines inhibits neurotoxicity of $\mathrm{A} \beta$ in vitro. ${ }^{14}$ In recent years, binding of Pt compounds ${ }^{15-18}$ to the metal binding site of $\mathrm{A} \beta$ have been studied. Barnham et al. ${ }^{15}$ showed that Pt(II)-1,10-phenanthroline complexes bind to $\mathrm{A} \beta$, inhibit aggregation and the generation of

\footnotetext{
${ }^{a}$ CSIRO Materials Science \& Engineering and Preventative-Health Flagship, Parkville, Victoria 3052, Australia. E-mail: Victor.Streltsov@csiro.au; Fax: +61 396627347; Tel: +61 396627311

${ }^{b}$ Florey Institute of Mental Health and Bio21 Molecular Science \& Biotechnology Institute, University of Melbourne, Parkville, Victoria 3050, Australia $\dagger$ Electronic supplementary information (ESI) available: Experimental details for the DLS, EXAFS, and MS experiments and the DFT calculations. See DOI: 10.1039/ c3cc47326k
}

reactive oxygen species, and rescue $A \beta$-induced synaptotoxicity in mouse hippocampal slices.

Knowledge of the atomic structure of the complexes made by Pt compounds with $A \beta$ would greatly facilitate $A \beta$-specific therapeutic and diagnostic development. Here we employed X-ray absorption spectroscopy (XAS), mass spectrometry (MS), dynamic light scattering (DLS) and density functional theory (DFT) to characterize and derive structural models of the interactions of cisplatin (cisPt) and $\mathrm{Pt}(4,7-$ diphenyl-[1,10]phenanthroline disulfonate) $\mathrm{Cl}_{2}\left(\mathrm{Pt}(\mathrm{BPS}) \mathrm{Cl}_{2}\right.$ ) with $\mathrm{A} \beta_{16}$ and $\mathrm{A} \beta_{42}$.

Barnham et al. ${ }^{15}$ suggests that $\mathrm{Pt}(\mathrm{II})-1,10$-phenanthroline complexes coordinate to the histidine residues of $A \beta$ while the methionine (Met35) also may be involved in the binding of cisplatin. Based on this and also more recent investigations ${ }^{16,17,19,20}$ using HPLC, ESI-MS, NMR, and EPR into the coordination of Pt(II) complexes to A $\beta$, His6, His13, and His14, and additionally Asp1 (N-terminus), Lys16 (A $\beta_{16}$ C-terminus) and Met35 can be considered as the potential ligands in $\mathrm{A} \beta_{16}$ or $\mathrm{A} \beta_{42}$ binding cisPt and $\mathrm{Pt}(\mathrm{BPS}) \mathrm{Cl}_{2}$.

Our DLS experiments demonstrated that $\mathrm{Pt}(\mathrm{BPS}) \mathrm{Cl}_{2}$ inhibited aggregation of the $\mathrm{A} \beta_{42}$ (Fig. S1 and text in ESI $\dagger$ ). We performed MALDI-TOF MS of complexes of $A \beta_{16}$ and $A \beta_{42}$ with cisPt and $\mathrm{Pt}(\mathrm{BPS}) \mathrm{Cl}_{2}$ (Fig. 1). The MS data suggests that addition of cisPt and $\mathrm{Pt}(\mathrm{BPS}) \mathrm{Cl}_{2}$ resulted in the formation of multiple binary complexes between the peptide and Pt-compounds. After $2 \mathrm{~h}$ of incubation with cisPt, the dominant metallated species observed was $\mathrm{A} \beta-\mathrm{Pt}$ (species I in Fig. 1a) for both $A \beta_{16}$ and $A \beta_{42}$ peptides, followed by complexes where cisPt lost either one (species V) or both (species IV) chloride ions for $A \beta_{16}$ or additionally either one or both $\mathrm{NH}_{3}$ groups in case of $\mathrm{A} \beta_{42}$ (Fig. 1a). When Pt(BPS)Cl ${ }_{2}$ binds to $A \beta_{16}$ or $A \beta_{42}$, it loses either one or both chloride ions as reported previously. ${ }^{15}$ Additionally, in case of $\mathrm{A} \beta_{42}$ it binds peptide with both chloride ions attached (species $\mathrm{V}$ in Fig. 1d) implying that this complex may bind through hydrophobic or/and $\pi-\pi$ non-covalent interactions of the phenanthroline motif with the hydrophobic C-terminal region of $A \beta_{42}$. Crosslinked oligomers and DMSO adducts were not observed by MS analysis.

Based on the MS results three-dimensional structural models for fitting the EXAFS spectra were constructed by performing 
a)

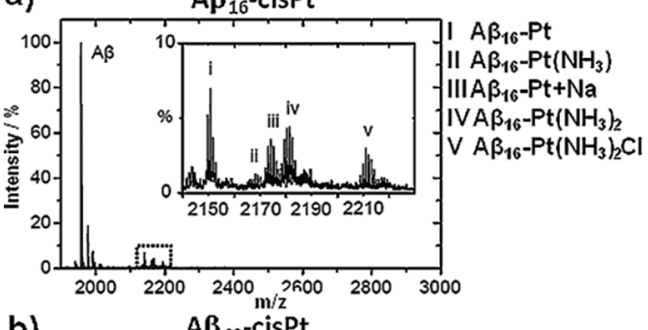

c)

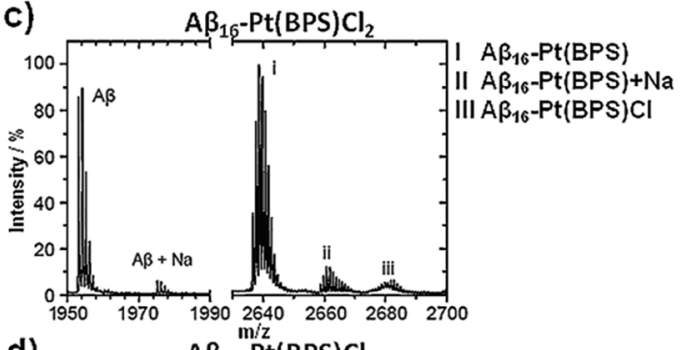

d)

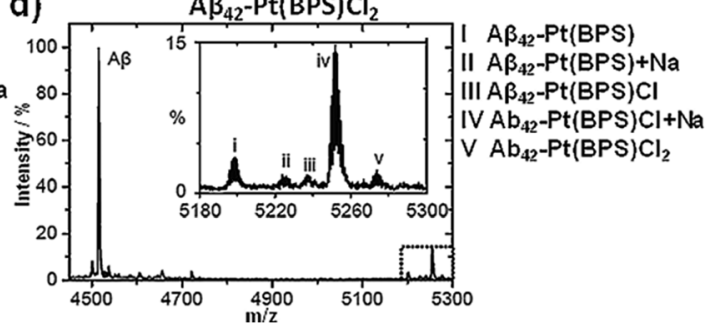

Fig. 1 MALDI-MS analysis of $A \beta_{16}(a, c)$ and $A \beta_{42}(b, d)$ complexes with cisPt $(a, b)$ and $\operatorname{Pt}(B P S) C l_{2}(c, d)$.

quantum mechanical calculations, optimizing the geometry of each model system with DFT (details given in ESI†). The DFT optimized geometries of studied complexes (Table S2 in ESI $\dagger$ ) were then refined against EXAFS spectra using multiple scattering theory ${ }^{21}$ considering an approximately planar, tetra-coordinated Pt atom. Fig. 2 presents refined Pt coordination geometries and the experimental and modelled EXAFS regions of Pt(II) spectra at $\mathrm{Pt} \mathrm{L}_{\mathrm{III}}$ edge and their Fourier Transforms (FT) for $\mathrm{A} \beta_{16^{-}}$ cisplatin, $\mathrm{A} \beta_{42}$-cisplatin, $\mathrm{A} \beta_{16}-\mathrm{Pt}(\mathrm{PBS}) \mathrm{Cl}_{2}$, and $\mathrm{A} \beta_{42}-\mathrm{Pt}(\mathrm{PBS}) \mathrm{Cl}_{2}$. The refined model included major species shown by MS (Fig. 1).
In the case of $\mathrm{A} \beta_{16}$-cisPt, the best fit was obtained with the mixture of the models including gradually replaced $\mathrm{Cl}$ and $\mathrm{NH}_{3}$ ligands with $\mathrm{A} \beta$ histidines and possibly with $\mathrm{N}$-terminus (Asp1), C-terminus (Lys16), or Asp7: ${ }^{16} \mathrm{Pt}-\left(\mathrm{NH}_{3}\right)_{2} \mathrm{Cl} 2, \mathrm{~A} \beta_{16}(\mathrm{His})-\mathrm{Pt}-\left(\mathrm{NH}_{3}\right)_{2} \mathrm{Cl}$, $\mathrm{A} \beta_{16}(\mathrm{His})_{2}-\mathrm{Pt}-\left(\mathrm{NH}_{3}\right)_{2}$ and $\mathrm{A} \beta_{16}(\mathrm{His})_{3}(\mathrm{~N} / \mathrm{O})-\mathrm{Pt}$ in accordance with MS data (Fig. 1a). The total populations of $\mathrm{N}\left(\mathrm{H}_{3}\right)$, $\mathrm{N}$ (His) and $\mathrm{Cl}$ were refined with fixed to physically meaningful values of $\sigma^{2}$ (Debye-Waller terms). In the case of cisPt-A $\beta_{42}$ complex, the best fit was obtained with mixture of two species: $\mathrm{A} \beta_{42}(\mathrm{His})_{3} \mathrm{~S}(\mathrm{Met} 35)-\mathrm{Pt}$ and $\mathrm{A} \beta_{42}(\mathrm{His})_{2} \mathrm{~S}(\mathrm{Met} 35)-\mathrm{Pt}-\left(\mathrm{NH}_{3}\right)$ in accordance

a)
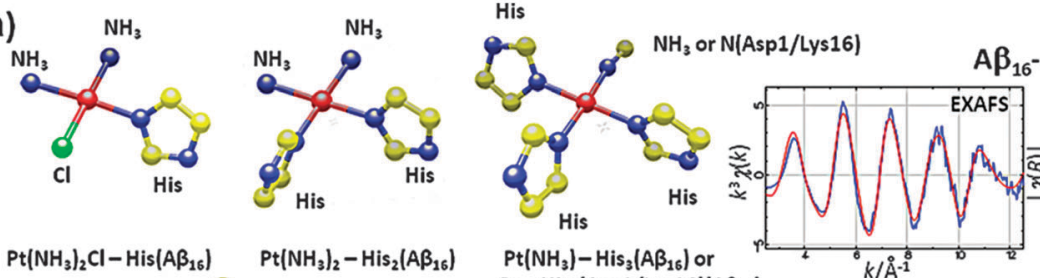

$A \beta_{16}$-cisPt

$\operatorname{Pt}\left(\mathrm{NH}_{3}\right)_{2} \mathrm{Cl}-\mathrm{His}\left(\mathrm{A} \beta_{16}\right)$

$\operatorname{Pt}\left(\mathrm{NH}_{3}\right)_{2}-\mathrm{His}_{2}\left(A \beta_{16}\right)$

$\mathrm{Pt}\left(\mathrm{NH}_{3}\right)-\mathrm{His}_{3}\left(A \beta_{16}\right)$ or $\mathrm{Pt}-\mathrm{His}_{2}$ (Asp1/Lys16) $\left(A \beta_{16}\right)$

b)

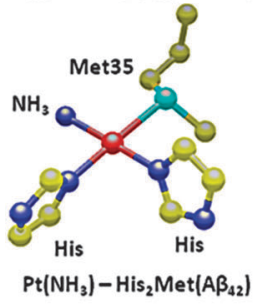

c)

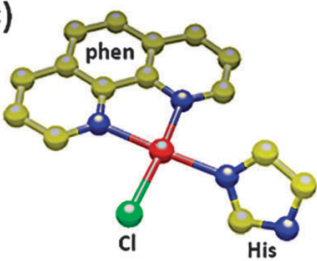

$\operatorname{Pt}(B P S) C l-H i s\left(A \beta_{16} / A \beta_{42}\right)$
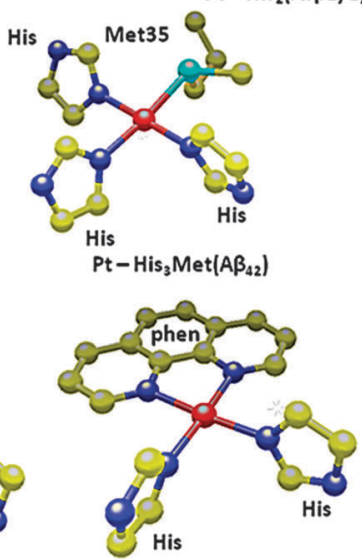

$\mathrm{Pt}(\mathrm{BPS})-\mathrm{His} \mathrm{s}_{2}\left(A \beta_{16} / A \beta_{42}\right)$

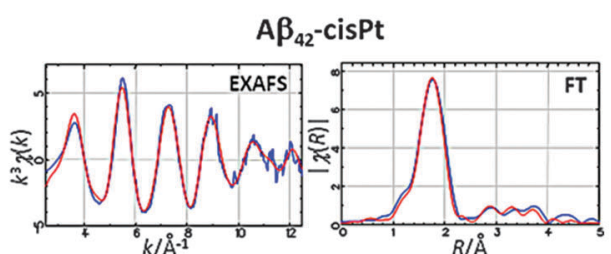
$\mathrm{A} \beta_{16}-\mathrm{Pt}(\mathrm{BPS}) \mathrm{Cl}_{2}$ and $\mathrm{A} \beta_{42}-\mathrm{Pt}(\mathrm{BPS}) \mathrm{Cl} \mathrm{C}_{2}$

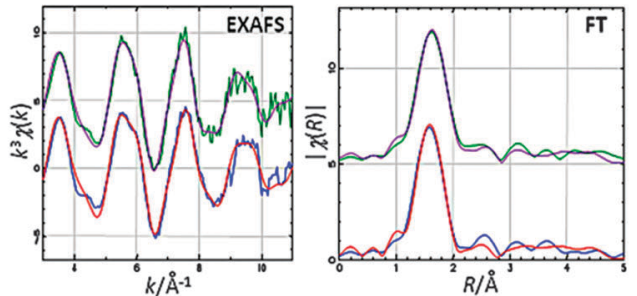

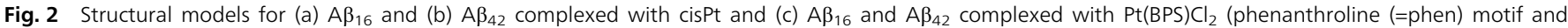

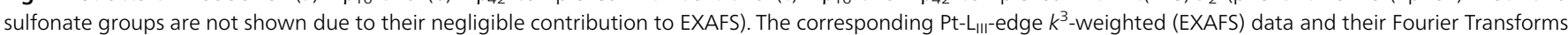
(FT) are shown in blue lines for the experimental data and in red for the best model fits. Atom colors: Pt-red, N-blue, C-yellow, Cl-green, S-cyan. 
with MS spectra (Fig. 1b). The result is consistent with previous ${ }^{1} \mathrm{H}$ NMR data for $\mathrm{A} \beta_{40}$ which showed that cisPt formed adducts with $A \beta$ and coordinated predominantly at the $S$ atom of Met35. ${ }^{15}$

Fig. 2c shows structures of the $A \beta_{16}-\mathrm{Pt}(\mathrm{PBS}) \mathrm{Cl}_{2}$ and $\mathrm{A} \beta_{42^{-}}$ $\mathrm{Pt}(\mathrm{PBS}) \mathrm{Cl}_{2}$ complexes fitted simultaneously to both experimental data sets. The high similarity in the XANES and EXAFS regions for the $\mathrm{A} \beta_{16^{-}}$and $\mathrm{A} \beta_{42}-\mathrm{Pt}(\mathrm{PBS}) \mathrm{Cl}_{2}$ complexes suggested that geometry of the $\mathrm{Pt}^{2+}$ coordination did not change significantly across the samples. Therefore we have attempted a multiple EXAFS data refinement for these complexes. Each of the two DFT optimized global models were used to simultaneously fit the two experimental spectra and resulted in predominant (phen)-Pt-A $\beta$ (His)Cl species in both cases.

The EXAFS refinement resulted (Table S3 in ESI $\dagger$ ) in the average $\mathrm{Pt}-\mathrm{N}\left(\right.$ imidazole), $\mathrm{Pt}-\mathrm{N}(\mathrm{phen}), \mathrm{Pt}-\mathrm{N}\left(\mathrm{NH}_{3}\right), \mathrm{Pt}-\mathrm{Cl}$ and

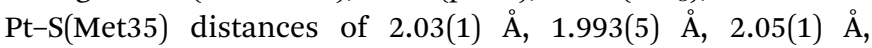

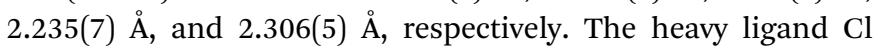
and $\mathrm{S}$ distances tend to be shorter than those calculated by DFT. However, they are close to the distances for Pt-N (2.04(1)-

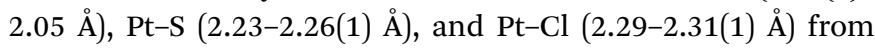
EXAFS fits for Pt-based anticancer drugs. ${ }^{22-24}$

The Pt complex Pt(BPS) $\mathrm{Cl}_{2}$ preferentially binds to the histidines of $\mathrm{A} \beta$. In contrast, although cisPt did form adducts with $\mathrm{A} \beta_{42}$, it coordinated predominantly at the $\mathrm{S}$ atom of Met35. cisPt has been reported to form DMSO adducts when prepared and kept in DMSO stocks. ${ }^{25}$ The formation of the cisPt DMSO adduct dramatically changes the reactivity and thus binding, of this complex $^{25}$ and the reported lack of interaction of $\mathrm{A} \beta_{16}$ with cisPt $^{16}$ may be due to this phenomenon. In our hands incubating cisPt with DMSO for 30 min resulted in formation of complexes such as $\mathrm{Pt}\left(\mathrm{NH}_{3}\right)_{2} \mathrm{~S}(\mathrm{DMSO}) \mathrm{Cl}$ identified by EXAFS analysis (not shown).

Even though the low affinity of ligand L (e.g. very low millimolar affinity of Pt-free 1,10-phenanthroline) for $\mathrm{A} \beta$ should result in short residency times with the intended target, the kinetic inertness of $\mathrm{Pt}$ complexes means that, once bound to the target, the L-Pt-A $\beta$ adducts are very stable and will not dissociate. The data presented here confirmed the hypothesis that the 1,10-phenanthroline complexes of $\mathrm{Pt}(\mathrm{II})$ coordinate to the histidine imidazole side chains of $A \beta$ and alter the biochemical and biophysical properties of the peptide. Because the Pt-complexes coordinate up to two histidine residues of $\mathrm{A} \beta$, they occupy the $\mathrm{Zn}, \mathrm{Cu}$ and $\mathrm{Fe}$ binding site on $\mathrm{A} \beta$ and so inhibit metal-mediated phenomena, such as ROS generation and enhanced aggregation. The bio-inactivity of cisplatin ${ }^{15}$ may indicate that the aromatic 1,10-phenanthroline scaffold coordinated to Pt(II) confers the necessary specific targeting of the Pt preferably to histidines His6 and His14 of $A \beta^{16}$ compared with the predominantly Met35 binding of cisplatin in our studies. The results achieved with the $\mathrm{L}-\mathrm{PtCl}_{2}$ complexes support the future development of this class of compound ${ }^{18}$ as therapeutic agents for $\mathrm{AD}$ to ensure they efficiently cross the blood-brain barrier. The potent effects of these Pt complexes define the histidine residues of $\mathrm{A} \beta$ as a viable therapeutic target to inhibit the neurotoxic and synaptotoxic actions of $A \beta$.
In this study XAS, MS and DLS experiments and DFT modelling were used to characterize and derive structural models of the interactions of Pt compounds with $A \beta$. Over the past few years, a number of small molecule compounds have been reported to bind to $A \beta$ and alleviate its toxic properties. Lack of experimentally determined structural models for many of their interactions with $A \beta$ is detrimental to developing effective therapeutics and diagnostics for AD. Our work reported here goes some way in addressing this deficiency.

\section{Notes and references}

1 G. M. Shankar, S. Li, T. H. Mehta, A. Garcia-Munoz, N. E. Shepardson, I. Smith, F. M. Brett, M. A. Farrell, M. J. Rowan, C. A. Lemere, C. M. Regan, D. M. Walsh, B. L. Sabatini and D. J. Selkoe, Nat. Med., 2008, 14, 837-842.

2 D. M. Walsh, I. Klyubin, J. V. Fadeeva, W. K. Cullen, R. Anwyl, M. S. Wolfe, M. J. Rowan and D. J. Selkoe, Nature, 2002, 416, 535-539.

3 M. A. Lovell, J. D. Robertson, W. J. Teesdale, J. L. Campbell and W. R. Markesbery, J. Neurol. Sci., 1998, 158, 47-52.

4 K. J. Barnham and A. I. Bush, Curr. Opin. Chem. Biol., 2008, 12, 222-228.

5 S. Rivera-Mancia, I. Perez-Neri, C. Rios, L. Tristan-Lopez, L. RiveraEspinosa and S. Montes, Chem.-Biol. Interact., 2010, 186, 184-199.

6 K. J. Barnham, C. L. Masters and A. I. Bush, Nat. Rev. Drug Discovery, 2004, 3, 205-214.

7 V. A. Streltsov and J. N. Varghese, Chem. Commun., 2008, 3169-3171.

8 J. W. Karr and V. A. Szalai, Biochemistry, 2008, 47, 5006-5016.

9 F. Stellato, G. Menestrina, M. D. Serra, C. Potrich, R. Tomazzolli, W. Meyer-Klaucke and S. Morante, Eur. Biophys. J., 2006, 35, 340-351.

10 V. A. Streltsov, S. J. Titmuss, V. C. Epa, K. J. Barnham, C. L. Masters and J. N. Varghese, Biophys. J., 2008, 95, 3447-3456.

11 S. C. Drew, C. L. Masters and K. J. Barnham, J. Am. Chem. Soc., 2009, 131, 8760-8761.

12 F. Bousejra-ElGarah, C. Bijani, Y. Coppel, P. Faller and C. Hureau, Inorg. Chem., 2011, 50, 9024-9030.

13 P. O. Tsvetkov, A. A. Kulikova, A. V. Golovin, Y. V. Tkachev, A. I. Archakov, S. A. Kozin and A. A. Makarov, Biophys. J., 2010, 99, L84-L86.

14 D. P. Smith, D. G. Smith, C. C. Curtain, J. F. Boas, J. R. Pilbrow, G. D. Ciccotosto, T. L. Lau, D. J. Tew, K. Perez, J. D. Wade, A. I. Bush, S. C. Drew, F. Separovic, C. L. Masters, R. Cappai and K. J. Barnham, J. Biol. Chem., 2006, 281, 15145-15154.

15 K. J. Barnham, V. B. Kenche, G. D. Ciccotosto, D. P. Smith, D. J. Tew, X. Liu, K. Perez, G. A. Cranston, T. J. Johanssen, I. Volitakis, A. I. Bush, C. L. Masters, A. R. White, J. P. Smith, R. A. Cherny and R. Cappai, Proc. Natl. Acad. Sci. U. S. A., 2008, 105, 6813-6818.

16 G. Ma, F. Huang, X. Pu, L. Jia, T. Jiang, L. Li and Y. Liu, Chemistry, 2011, 17, 11657-11666.

17 I. Sasaki, C. Bijani, S. Ladeira, V. Bourdon, P. Faller and C. Hureau, Dalton Trans., 2012, 41, 6404-6407.

18 V. B. Kenche, L. W. Hung, K. Perez, I. Volitakes, G. Ciccotosto, J. Kwok, N. Critch, N. Sherratt, M. Cortes, V. Lal, C. L. Masters, K. Murakami, R. Cappai, P. A. Adlard and K. J. Barnham, Angew. Chem., Int. Ed., 2013, 52, 3374-3378.

19 G. L. Ma, E. Q. Wang, H. Wei, K. J. Wei, P. P. Zhu and Y. Z. Liu, Metallomics, 2013, 5, 879-887.

20 F. Collin, I. Sasaki, H. Eury, P. Faller and C. Hureau, Chem. Commun., 2013, 49, 2130-2132.

21 A. L. Ankudinov, A. I. Nesvizhskii and J. J. Rehr, Phys. Rev. B, 2003, 67, 115120

22 D. Bouvet, A. Michalowicz, S. Crauste-Manciet, D. Brossard and K. Provost, Inorg. Chem., 2006, 45, 3393-3398.

23 D. Bouvet, A. Michalowicz, S. Crauste-Manciet, E. Curis, I. Nicolis, L. Olivi, G. Vlaic, D. Brossard and K. Provost, J. Synchrotron Radiat., 2006, 13, 477-483.

24 K. Provost, D. Bouvet-Muller, S. Crauste-Manciet, J. Moscovici, L. Olivi, G. Vlaic and A. Michalowicz, Biochimie, 2009, 91, 1301-1306.

25 S. J. Fischer, L. M. Benson, A. Fauq, S. Naylor and A. J. Windebank, Neurotoxicology, 2008, 29, 444-452. 